\title{
A critical assessment of Bediako's incarnational Christological model as a response to the foreignness of Christ in African Christianity

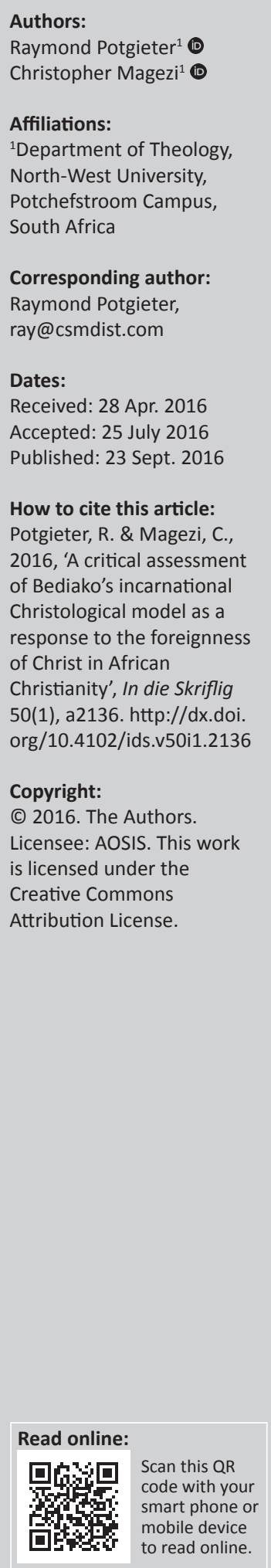

Some African Christians continue to rely on traditional spiritual powers as a means of addressing their spiritual insecurity. In their perception Christ is regarded as being foreign to African spirituality and treated accordingly with the gospel seen as a predominantly western phenomenon. This raises the question regarding their understanding of Christ's incarnation. This article critically analyses the ancestral incarnational Christological model of Bediako as a response to the foreignness of Christ in African Christianity. Bediako's ancestral incarnational Christological model is his enterprise of deforeignising Christ in African Christianity by treating Christ under the African traditional ancestral category. This article demonstrates various theological aspects (i.e. the uncompounded divine-human nature of Christ in the one eternal person of the Son of God) that Bediako brings together in order to configure his ancestral incarnational Christological framework in deforeignising Christ. In breaking away from Bediako's ancestral incarnational Christological perspective, the article concludes by identifying the weaknesses associated with the proposed concept of Bediako, and then suggests that there is a need for an alternative biblical-theological model that best describes Christ's complete identification with African Christians. This is done without diminishing the actuality of Christ as God incarnate, or encouraging syncretism in African Christianity, or reducing the validity of African contextual needs.

\section{Introduction}

There is a considerable amount of research (Anderson 2001:98-11; Kok 2005:95-101; Kunhiyop 2012:59; Light 2010:21-22; Michael 2013:99; Nurnberger 2007:8-42; Wijsen 2000:37-60) which indicates a form of Christian syncretism. The latter becomes evident in some African Christians' use of African traditional powers to address traditional religious spiritual threats such as witchcraft and angry ancestral spirits. Christians continue to rely on African traditional powers partly because they perceive Christ as a foreigner, unable to address their particular spiritual insecurity (Banda 2005:4-5, 27). This raises questions regarding some African Christians' understanding of Christ's incarnation.

In an attempt to grapple with the problem of the foreignness of Christ in African Christianity, this article gives a critical assessment of Bediako's incarnational Christological model as a response to the proposed problem. In order to achieve this goal, the first section will discuss the basis on which some African Christians perceive Christ as a foreigner. The basis on which African Christians perceive Christ as unrelated to them includes the central traditional African ancestral worldview which requires a blood-related ancestor in order to address their spiritual insecurity, as well as the newness of Christ in African religiosity. This has been further intensified by the missionary era of Christianity, which presented Christ from a predominantly western perspective. The second section will consider Bediako ${ }^{1}$ (1995:217; 2004:23) as one among many African theologians who have attempted to address the foreignness of Christ in African Christianity by treating Christ under the traditional African concept of ancestors. Bediako's Christ-deforeignising concepts, namely the uncompounded divine-human nature of Christ, the interconnection between the doctrine of creation and redemption and the African believers' appropriation of the divine promises given to the patriarchs of Israel through faith in Jesus Christ will be discussed. At this juncture, the challenges associated with Bediako's application of the ancestral category to Christ will also be established. Once this is done, the article will then conclude by suggesting that there

1.Kwame Bediako was one of the most influential African theologians and pastors of the late 20 th century (Asamoah-Gyadu $2009: 5$ Omenyo 2008:388). He was born on 7 July 1945 and died at the age of 63, on 10 June 2008 (Asamoah-Gyadu 2009:5, 10; Obituary 2009:7; Omenyo 2008:387; Walls 2008:188). Aho Ekue (2005:105) declares: There are those African theologians who are influenced by debate and culture, who stress the necessity of the translation of the gospel into the realities of the people. Here Bediako seems to be one of them (p. 105). 
is a need for an alternative biblical-theological model that best describes Christ's complete identification with African Christians - without diminishing the actuality of Christ as God incarnate, or encouraging syncretism in African Christianity, or reducing the validity of African contextual needs.

\section{The foreignness of Christ as an incarnational Christological challenge}

\section{An incarnational Christological challenge stemming from the African ancestral worldview}

Even though African scholars and theologians find it difficult to speak of African traditional worldview or views as a unitary phenomenon, ${ }^{2}$ they concur that within the diverse beliefs of traditional African cultures is the common worldview of the interconnection between the spiritual and physical worlds (Dyrness 1990:44; Louw 2002:72; Lugira 2009:48; Mbiti 1989:74-85; Turaki 2006:34). Mbiti (1989) encapsulates the interconnection between the physical and the spiritual worlds in his statement that:

the spiritual universe is united with the physical, and that these two intermingle and dovetail into each other so much that it is not easy, or even necessary, at times to draw the distinction or separate them. (p. 74)

In this way, various African cultures recognise that the spirit world is inhabited by many spiritual powers, which are in a hierarchical relationship with one another; acting capriciously as an unpredictable influence of good and evil in the lives of Africans (Imasogie 1983:53-54; Light 2010:99-109; Lugira 2009:36-63; Mashau 2009:117; Mbiti 1989:77-80; Turaki 2006:54-66). In concurrence with some African theologians and scholars Turaki (2006) depicts the multiplicity of spiritual powers and their hierarchy by maintaining that:

African theologians and scholars speak about the transcendence of God, the Supreme Being, and claim that the space between God and human beings is filled with a hierarchy of gods, divinities and spirits who are sometimes called the intermediaries. (p. 61)

Inherent within the African traditional worldview is ancestral veneration, which occupies a central place in traditional African religion (Triebel 2002:193; cf. Dyrness 1990:48; Reed \& Mtukwa 2010:148). The ancestors are those blood-related members of the family, clan or tribe who have lived an outstanding life and who have supposedly thereby acquired supernatural powers after death. This enable them to function as both guardians and protectors of their living descendants (cf. Bediako 2004:23; Ligura 2009:48-50; Nyamiti 2006:3, 9; Oladosu 2012:160-161). The ancestors are viewed as being closer to living people than any other spiritual power, and they can either harm or bless their living descendants depending on the existing relationship between them (ancestors and the living people) (Oladosu 2012:161; Triebel

2.Mbiti (1989:76) supports the concept that in Africans' belief in spiritual powers 'obviously there are local differences, but the pattern is fairly uniform throughout the traditional environment'.
2002:187, cf. Dyrness 1990:48; Mbiti 1989:82). This is why Triebel (2002) captures the centrality of ancestors in African traditional beliefs by concluding the following:

Because the ancestors cause misfortune on the one hand and because on the other hand only they can grant fortune, wellbeing, life, and a good living - that is, fullness of life - they alone are venerated ... Therefore this cult is really the central aspect, the center of African religion. (p. 193)

Given this, for Christ to be accepted by Africans and fulfil the expected responsibilities in addressing their spiritual insecurity (which is believed by Africans to be the role of ancestors and other African traditional practitioners), the overarching concern is about the familial relationship between Jesus Christ of Nazareth and the African people since the two do not belong to the same 'clan, family, tribe and nation' (Bediako 2004:23; Pobee 1979:81; Reed \& Mtukwa 2010:158-161). Owing to this perceived unrelatedness between Jesus Christ and African people, many African Christians '... are uncertain about how the Jesus of the church's preaching saves them from the terrors and fears that they experience in their traditional worldview' (Bediako 2004:23). Once Christ is depicted as a foreigner it is perceived that he is unable and insufficient to address the spiritual insecurity of African Christians (Banda 2005:4-7). This requires the dispelling of the foreignness of Christ in African Christianity by providing a biblical explanation of the nature and extent of Christ's incarnation. In doing this, African Christians ought to fully identify themselves with Christ, as well as understanding Christ's involvement in all their existential challenges.

\section{An incarnational Christological challenge stemming from the newness of Christ to African religiosity}

The foreignness of Christ in African Christianity is further deepened by the newness of Christ in African religiosity (Banda 2005:4). Since we are aware that newness is not necessarily foreignness, we are simply avowing that the unfamiliarity of Africans with Christ in their traditional African worldview increased the notion of Christ as foreign to them. This newness of Christ in the traditional African worldview has created difficulties for the conceptualisation of Christ in African terms for many African Christians (Banda 2005:4; Mugabe 1991:343). It is important to point out that in the common African worldview of spiritual powers, God's existence is a universal feature (cf. Agyarko 2010:52-54; Imasogie 1983:66; Lugira 2009:36; Mbiti 1989:15-77) while Jesus is not part of the traditional African belief system. Hood (1990) agrees with the aforementioned analysis as he argues that:

theologically the Afro traditionalists affirm the supreme god as one who reigns over a cosmos that includes not only humankind, but also spirits, divinities, ancestors, and other forces in animate and inanimate beings. (p. 145)

Hood (1990:145) is moving towards his conclusion concerning the newness and foreignness of Christ in the 
African traditional worldview, namely that it is not the Christian God who causes problems for Afro cultures; it is the Christian Christ'. Therefore as a result of Jesus Christ's newness within the African traditional worldview, many African Christians seem to be unaware of how Christ relates to them, as well as of how he saves them from their fears of spiritual powers.

\section{Christ's foreignness and the early western missionary era of Christianity in Africa}

Banda (2005:5) affirms that the newness and foreignness of Christ in African religiosity is also connected to '... the fact that Jesus Christ was not part of African religiosity until the arrival of Western missionaries'. The notion within the shared understanding in scholarship is that the early western missionaries arrived in Africa and imposed their presupposedly superior worldview upon African people 'mainly at a presuppositional level' (Hutchison 1982:174, cited in Bosch 1993:292). Most missionaries are believed to have presented Jesus Christ in Africa in a way which depicted him (Christ) as a westerner by identity (Ezigbo 2008:2-17; Taylor 1963:16; Waliggo 1998:111-112). Therefore, they presented Christ as only capable of meeting the needs of that worldview.

In this respect some of these missionaries were concerned with the promotion of their civilised western culture (Aguwa 2007:127-128; Setiloane 1976:89). They were convinced that their cultural beliefs were superior to traditional African beliefs. Interestingly, the western missionaries' mindset that their cultural beliefs and practices were superior to Africans' traditional beliefs was dominant to the extent that any cultural differences between the western missionaries and the particular group of Africans involved 'would have been mere evidence of how depraved and uncivilized the lower (African) races were' (Setiloane 1976:89). In doing this the early western missionaries presented Christ as a westerner, who is primarily concerned with the existential challenges of the western worldview. This is why there is a shared understanding among African theologians that most early western missionaries were dismissive of African traditional beliefs in the invisible forces, which have real negative impact on their lives (Adewuya 2012:253-254; Aho Ekue 2005:102; Ezigbo 2008:2-18; Ishola 2002:44-60). These missionaries dismissed some African traditional beliefs by regarding them as merely superstitions or irrational beliefs that could be addressed by a process of civilisation (cf. Ezigbo 2008:2-17; Haar 2009:45; Imasogie 1983:46-53; Ncozana 2002:147).

The superiority complex of western missionaries led to their pessimistic attitudes towards traditional African beliefs as the negative influences of spiritual powers in the lives of Africans. Scholars argue that some western missionaries were influenced by the Enlightenment Age of the 18th century (Bosch 1993:263-266; Imasogie 1983:51; Kalu 2007:7; Salala 1998:137; Shaw 1996:129). Bosch (1993:262) sharply contends that both the Protestant and Catholic missionaries of the 18th century were 'in one way or another, profoundly influenced by the Enlightenment'. This influence was rooted in two of the Enlightenment's scientific approaches, which exalted the autonomy of humanity (Bosch 1993:263). The first scientific approach was the 'Age of Reason' in which human reason or mind was considered as the basis of knowledge (1993:264). This new method in perceiving reality advocates for the breakaway from the 'norms of traditions or presuppositions' (1993:264). The second scientific approach was Bacon's 'empirical approach' which posits nature as the physical object for inquiry by humanity, instead of its apprehension as God's creation (1993:264). In this way people's direct experience (sensory experience) determines the validity of their traditional beliefs or assumptions (1993:264-267). In this situation these scientific approaches have influenced the way in which some early western missionaries viewed reality.

The quest for correspondence and similarities: Whether the early western missionaries dismissed the African traditional beliefs in spiritual powers unintentionally or deliberately, the truth is that these missionaries downplayed the fundamental African belief concerning the interrelationship between the physical and metaphysical worlds. This took place despite the fact that Scripture (Eph 6:12) supports this concept ${ }^{3}$ (Adewuya 2012:251-258; Amanze 2011:9-11; Ejenobo 2009:77; Imasogie 1983:52-53; Oladipo 2010:40-43). In this case instead of rejecting the African belief in invisible powers, the missionaries should have accepted the existence of the invisible powers on the basis of Scripture (and affirmed the African perception of them). They then should have analysed and evaluated the African conception of the spiritual powers against the backdrop of Scripture and outlined its inconsistency. Kunhiyop (2012:53) correctly points out that the African traditional religion superficially correlates with the biblical concept of God as the sole creator of everything, including the spiritual powers, which occupy the invisible world. These spiritual powers have either a 'positive or negative impact' on all dimensions of African peoples' lives. Therefore, African traditional worldview seemingly correlates with the biblical worldview concerning some antithetical categories of spiritual powers as either good or evil in their nature (2012:53). Thus one should acknowledge the existence of the spirit world, since the spiritual powers exist from a scriptural perspective, and they are scripturally categorised.

Basic research assumption: In view of the above-mentioned discussion, this article subscribes to the understanding that in most cases, western missionaries' 'cultural superiority informed their approach, with a conflation between Christianity and European culture shaping their vision' (Chitando 2005:184). In doing this they have painted Christ as a westerner and the Saviour with a western worldview; that is making Christ irrelevant and foreign in addressing the

3.The apostle Paul in Ephesians $6: 12$ posits the actual existence of the spiritual forces and its impact on humanity. Paul argues that the argues thattence of the spiritual and its impact on humanity. Paul argues that the argues thattence of the spiritual forces and its impact on humanity. hroughout the traditional envi's) message has a real impact on his contemporary audience (Adewuya 2012:251-258; Amanze 2011:9-11; Imasogie 1983:52). In this way Paul states that the struggle of believers is not against the flesh or blood; instead it is against the powers of darkness and the spiritual forces of evil. Nevertheless, irrespective of this reality, some missionarie preached Ephesians 6:12 to Africans, yet disconnected this verse'rrespective of this rea's contemporary audience (the Ephesian believers), as well as the African Christians (current audience) (Imasogie 1983:52). 
spiritual insecurity of African Christians. In this way 'many Africans perceive Jesus as both a foreign and new idea', specifically with his 'initial emergence and association with white settlers' (Banda 2005:5). This is why Taylor (1963) concludes:

Christ has been presented as the answer to the questions a white man would ask, the solution to the needs that western man would feel, the Saviour of the world of the European world-view, the object of the adoration and prayer of historic Christendom. But if Christ were to appear as the answer to the questions that Africans are asking, what would he look like? (p. 16)

Given this, the African Christians' perception of Christ as a western Saviour is a significant incarnational Christological challenge, which requires the deforeignisation of Christ in African Christianity. Otherwise without dispelling the foreignness of Christ by delineating the nature and extent of Christ's incarnation, African Christians will not understand how Christ identifies with them, and addresses their spiritual insecurity (Banda 2005:6). As a result African believers will continue to reflect:

... a religious syncretism that is suitable to their social requirements, going to church on Sundays, but consulting the traditional religious priests during the weekdays. Perhaps this is one of the reasons why in theological circles in the African continent, there is a cry for a contextualization of the Christian's faith within the African society. (Ejenobo 2009:77-78)

\section{Bediako's ancestral incarnational Christological concept in deforeignising Christ in African Christianity}

\section{Bediako's use of the incarnate uncompounded divine-human nature of Christ in deforeignising Christ}

Although Bediako (2004:24-33) does not use the term ancestral incarnational Christology directly, his theology of the deforeignisation of Christ nevertheless reflects an incarnational Christological perspective. That is, although he does not use the word incarnation in his title of ancestral Christology, the concept of incarnation is primal in his employment of the aforementioned concept as will be demonstrated below.

In line with the creed of Chalcedon (in AD 451), Bediako (1994:98-121; 2004:24-33) uses the controlling aspect of the uncompounded divine-human nature of Christ to solve the problem of the foreignness of Christ in African Christianity. This problem is integral within the African traditional ancestral worldview, which requires a blood-related ancestor in order to redeem African Christians from their spiritual insecurity (Bediako 1994:96-99; 2004:23-25). However, in order to dispel the foreignness of Christ, Bediako (2004:24) argues for the universality of Christ by starting from his divine origin as God. His deforeignisation of Christ (in African Christianity) commences from Christ's divine origin yet does not downplay Jesus' particularity as a Jew. Bediako (2004:24) puts it this way: 'by insisting on the primacy of
Jesus' universality, we do not reduce his incarnation and its particularity to a mere accident of history'. By beginning from the divinity of Christ, Bediako's (2004:24-25) intention is to show African Christians that '... Jesus Christ is not a stranger' to them, since the divinity of Christ points African Christians to the fact that in the incarnation God the Creator came within space and time to identify himself with all humanity. Also in Bediako's (1995:84-85) view, the divinity of Christ points us to the sovereignty or supremacy of Christ over the ancestors. This is evidenced in Bediako's (1995: 84-85) entire discussion of his ancestral Christology, in which the divinity of Christ is central to His (Christ) sovereignty over the ancestors and all other spiritual forces.

Therefore, in order to deforeignise and Africanise Christ by emphasising his divinity, Bediako grounds the divinity of Christ within the trinitarian concept of the one being of the Son with the Father, so as to show that Jesus Christ was truly God (Bediako 1994:99-101; 2004:24-25). In upholding the oneness of the Son with the Father, Bediako is in agreement with the Nicene creed of AD 325 which states the actuality that Jesus Christ is '... of one substance with the Father' in being (Schaff \& Wace 1991:3). Bediako understands that 'Evangelical theology is simply trinitarian theology' in nature (Nkansah-Obrempong 2010:294). In saying this Bediako agrees with Nyamiti (1989:31) who contends that 'all truly profound theology must therefore be ultimately rooted in the Trinity - so much so that without this grounding it is bound to be radically superficial'. This is because 'without the Trinity, Christ himself (and hence, Christology) would lose his personality' (1989:31). In other words Bediako (2004:25) understands that the being of Jesus Christ is identical to God and can only be maintained by grounding his divinity in the Christian doctrine of the Trinity, so as to retain Jesus Christ's pre-existence (as truly God) in the mystery of incarnation.

Thus in stressing the oneness of the Son with the Father, Bediako (2004:24-25) understands that for universal and adequate salvation to take place, one should preserve the unity between the doctrine of the trinity and the incarnation. In arguing for the one existence of the Son with the Father, Bediako $(1994: 101 ; 2004: 25)$ has in view the doctrine of universal sin. That is to say, due to the doctrine of $\sin$ Bediako is cognisant of 'the relevance and importance of a Christ who is both true God and true man' as 'radically and essentially different from that of Jesus who is a mere man, however perfect a man he might be' (Nyamiti 1989:31). Therefore in substantiating the one being of the Son with the Father, Bediako (1994:100-101; 2004:24-25) uses John 1:18 to reinforce that it is God the Son who is of one substance with the Father, who was incarnated and became deeply involved in the condition of sinful humanity. In affirming this Bediako is in agreement with Bujo's (1992:82) prolonged description of the fact that in the mystery of the incarnation 'God so truly became part of this world, part of the reality and of the history of the cosmos'. Therefore the 'meeting between God and humankind in this mystery (of incarnation) is the highest stage in the realisation of the human identity' (Bujo 1992:82). 
In further confirmation of his understanding of the uncompounded divine-human nature of Christ, Bediako (2004) outlines that it is in the mysterious act of the incarnation that Christians are confronted by the redemptive reality that:

God humbled himself and identified with human kind in Christ's birth as a human baby, born of woman, and endured the conditions of 'normal' human existence - in other words the incarnation is the unique sign and demonstration of divine vulnerability in history. (pp. 41-42)

Once the divine-human nature of Christ is grounded in the trinitarian concept, Bediako is ready to move to a conclusion in which he approaches 'the doctrine of Christ under the figure of ancestor' (Olsen 1997:259). That is to say, the humanity which Christ assumed in the incarnation is universal. This means Christ is the ancestor of every Christian, including African Christians (Bediako 1994:99-118, 2004:24-33). One must suggest that Bediako's viewpoint raises a problem, since it is one thing to say Christ shares our humanity, and another thing to say that he is our ancestor. In other words, one can ask Bediako the following question: Does Christ's sharing in our humanity make him our ancestor? One supposes this is a problem because the Bible does not present Christ as an ancestor, ${ }^{4}$ and the dangers of this approach will be discussed in 'A critical assessment of Bediako's ancestral incarnational Christological framework' later on. Nevertheless, in spite of this potential criticism, Bediako $(1994: 99 ; 2004: 24)$ emphasises that in the incarnation the Son of God became the 'Saviour for all people, of all nations, and of all times'. That is to say:

\begin{abstract}
... Jesus Christ, himself the image of the Father, by becoming one like us has shared our human heritage. It is within this human heritage that he finds us, and speaks to us in terms of its questions and puzzles. He challenges us to turn to him and participate in the new humanity for which he has come, died, been raised and glorified. (Bediako 1994:100, 2004:24)
\end{abstract}

Nevertheless, the challenge one faces in attempting to figure out Bediako's use of the uncompounded divine-human nature of Christ to deforeignise and to Africanise him in context, is the following: Bediako neither explores nor develops the theological meaning of the doctrine of incarnation. Rather he assumes the validity of the Christian doctrine of the incarnation established by the councils of Nicea (in AD 325) and Chalcedon (in AD 351), and then applies this doctrine to the traditional African worldview of ancestral veneration, which requires a blood-related ancestor in order to address African peoples' spiritual insecurity. Bediako does not have a comprehensive treatment of the doctrine of incarnation; therefore his incarnational theology does not demonstrate to us how the

4.The reason for Bediako's designation of the ancestral category on Christ is that he parallels God's revelation of himself in Jewish culture to African traditional culture. Thus he justifies the use of a category in which God was at work revealing himself in the same way He used the priestly category of the Jews. This approach is evident in Bediako's (1995) argument that: ... a theology of ancestors is about the interpretation of the past in a way which shows that the present experience and knowledge of the grace of God in the Gospel of Jesus Christ have been truly anticipated and prefigured in the quests and the responses to the Transcendent in former times, as these have been reflected in the lives of African people (pp. 224-225) various tenets of the Christian doctrine of the incarnation are related to his endeavour of deforeignising and Africanising Christ. Once this is granted, it is difficult for us to present Bediako's broad theological understanding of the incarnation in relationship to his ancestral incarnational Christological construct.

\section{Bediako's use of the interconnection between the doctrine of creation and redemption in deforeignising and Africanising Christ}

Bediako (2004:25) further attempts to address the foreignness of Christ by depicting a close relationship between the doctrine of creation and redemption. He argues that the beginning verses of John's Gospel (1:1-14) echo the doctrine of creation in which the divine Logos (Jesus Christ) is the creator of the universe and everything in it. This implies that Jesus Christ has been the source of life for everyone. He (2004:25) understands the creation of the first man (Adam) to be the first revelation of God to humanity, as well as God's first covenant with human beings (Gn 1). In doing this Bediako (2004:25) is moving towards his crucial point that 'it was in the creation of the universe and especially of man that God first revealed his kingship to our ancestors and called them to freely obey Him'. In correspondence with the traditional African worldview of God as the originator or creator of everything, he (2004:25) further claims that the Scriptural doctrine of creation has an immense implication for the traditional worldview of Africans, since Africans 'are given more biblical basis for discovering more about God within the framework of the high doctrine of God as Creator and Sustainer' of everything.

Moreover, the doctrine of $\sin (\mathrm{Gn} 3)$ is very important for Bediako (2004:25), since it stresses the entrance of sin into the world, which brings forth some abiding negative effects in all aspects of the lives of humanity. In locating a contrast between Adam and Christ (cf. 1 Cor 15:22), Bediako (2004:25) argues that Scripture clearly indicates that all human beings die in Adam, since as our first ancestor he sinned and disregarded his privilege of being under God's place, presence and rule. In affirming this Bediako is agreeing with Nyamiti's (2006) delineation:

Christ (the New Adam), the Head and Ancestor of the new humanity, is contrasted with the first Adam by being presented as comparably more beneficial to his descendants as Adam was injurious to them. (p. 12)

In bringing the universal fall into perspective, Bediako (2004) is sustaining the reality that:

the experience of ambiguity that comes from regarding the lesser deities and ancestral spirits as both beneficent and malevolent can only be resolved in a genuine incarnation of the Saviour from the realm beyond. (p. 25)

The incarnation is thus closely related to the reality that Christ is the creator and the sustainer of everything. Based on his eternal sense (not biological sense), Christ is warranted as the source of life for African Christians. This is in direct 
contrast to some African Christians' attribution of this aforementioned role of the source of life to their former traditional ancestors. In other words in Bediako's treatment of Christ in the ancestral category, he dismisses the foreignness of Christ in African Christianity by arguing for a close association between the doctrine of creation and redemption (cf. Col 1:15ff.), in which both creation and redemption are accomplished 'in and through Jesus Christ', the universal ancestor (Bediako 2004:25).

\section{Bediako's use of African believers' appropriation of the divine promises given to the patriarchs of Israel to deforeignise and Africanise Christ}

Bediako's establishment of the universality of Christ as the ancestor of African Christians through the doctrine of the incarnation, and the close association between the doctrine of creation and redemption, do not exclude the particularity of Jesus Christ as a Jew (Bediako 1994:99). As Wagenaar (1999:371) acknowledges, Bediako 'returns to the traditional theology that chooses its beginning in the particular perspective of Israel, but then contains a universal promise'. He understands that faith is central for universalising the divine promises given to the patriarchs of Israel and to Israel as a nation (Bediako 1999:99-100). Bediako integrates Old Testament and New Testament theology. He confirms that the divine promises given to the patriarchs of Israel (and Israel as a nation) are part of the existences of the Jews and Gentiles based on their faith in Christ, who fulfilled all the Old Testament promises. He thus understands that the Old Testament and New Testament make out the movement of one redemptive story, which should be interpreted in Christ as its centre.

In other words, through faith in the incarnate Son of God, African Christians 'share in the divine promises given to the patriarchs and through the history of ancient Israel' (Bediako 1994:99). In this way those promises belong to African Christians because even though Christ's salvation is 'from the Jews' (Jn 4:22), it is not 'thereby Jewish' (1994:99-100). This is clearly indicated in Bediako's apprehension that Jesus in John's Gospel (Jn 8:43-44) identifies the Jews who were not listening to his words as the children of the devil, not of Abraham. This was offensive from the Jewish perspective, since they had the right to physically identify themselves with Abraham. Romans 4:11-12 becomes the centrepiece for Bediako's appropriation of the Gentiles, including Africans, as sharing in the Abrahamic promises. Gentiles appropriate the Abrahamic promises as they believe in Jesus Christ, who both fulfilled and extended the Abrahamic promises to all who believe in him. Thus in paraphrasing Romans 4:11-12, Bediako (ibid. 100) concludes that the true children of Abraham are those who put their trust or faith in Jesus Christ in the same way that Abraham trusted in God'. ${ }^{5}$

Once this is established, Bediako (1994) unswervingly maintains that:

5.In this regard, commentators like Cranfield (1975:234-238), Hultgren (2011:183-182 and Kruse (2012:208-211) are in support of Bediako's interpretation of Romans 4:11-12. our true identity as men and women made in the image of God, is not to be understood primarily in terms of racial, cultural, national or lineage categories, but in terms of Jesus Christ himself. (p. 100)

Walls (2008:191) argues that while Bediako depicts the particularity of Jesus as a Jew; he also argues for the universality of both the Abrahamic and Israelite promises in terms of the adoptive past, in which African Christians are covenantally joined to the promises through faith in Jesus Christ. This means that through faith in Jesus Christ, all Christians 'share the same ancestors and those ancestors belong to every tribe, kindred, and nation'. From Bediako's discussion and integrated theological insights into an ancestral incarnational Christological concept, he attempts to dispel the foreignness of Christ in African Christianity.

\section{A critical assessment of Bediako's ancestral incarnational Christological framework}

It is our contention that Bediako's ancestral incarnational Christological model reveals a tendency to diminish the actuality of Christ as God incarnate and to encourage syncretism in African Christianity. Although Bediako (1995:85) is aware of the challenge of relevance without syncretism, one should acknowledge that his designation of Christ as an ancestor does not do justice to the supremacy of Christ, or to the qualitative distinction between Christ and the African traditional ancestors (Mkole 2000:1138). In other words, even though we have just argued strongly that Bediako does uphold Christ's supremacy, his application of the ancestral category to Christ seems to compromise the supremacy of Christ. It is the supremacy of Christ over the spiritual universe (or the qualitative distinction between Christ and the African traditional ancestors), which Christ himself achieves and profoundly supersedes through his redemptive acts rooted in the mystery of his salvific incarnation. The conceptualisation of Christ as an ancestor seems to make African Christians think of Christ as merely human, instead of God incarnate (Mkole 2000:1138; Palmer 2008:71; Reed \& Mtukwa 2010:157). This encourages some African Christians to conceptualise Christ in their former understanding of natural ancestors, which can equate their natural ancestors with Christ at the expense of the actuality that Christ transcends the ancestral category (Mkole 2000:1138; Palmer 2008:71; Wacheche 2012:28).

Even though Bediako's application of the ancestral category to Christ takes the African traditional worldview of ancestor seriously, this endeavour seems to undermine the supremacy of Christ over the spiritual universe (Afeke \& Verster 2004:59). It is reminiscent of the danger of encouraging African Christians to continue thinking of Christ in view of their former traditional understanding of ancestors, yet Christ is the incarnate God whose 'Lordship, authority and Supremacy can meet all spiritual needs' (2004:59). This means that Bediako's contextualisation hypothesis, in its treatment of Christ under the category of ancestor, actually compromises the cosmic 
dimension of Christ's deity. Since Christ is God incarnate, he transcends the African ancestor category which makes the concept unsuitable for a biblically based Christology. Maybe this is why the Christological paradigm and metaphorical expression of Christ as an ancestor lacks practical value at the grassroots level in African Christianity (Olsen 1997:251). Palmer (2008:65) similarly contends that many Protestant and Catholic theologians 'have referred to Jesus as an ancestor. Yet at grassroots there is still significant resistance to such a concept'. Once the problems are granted, it is apparent that the conceptualisation of Christ as ancestor can exhort African Christians to continue to perceive their natural ancestors as intermediators between Africans and God (Reed \& Mtukwa 2010:157). African Christians can thus continue to hold on to Christ and their natural ancestors for spiritual security, since they will perceive no distinction between the two (Christ and their natural ancestors). Therefore, African Christians can continue to worship their former traditional ancestors by placing them 'in a position that only God should hold by offering them sacrifices and oblations' (2010:157).

Having said the aforementioned, we are aware that in Transforming mission: Paradigm shifts in theology of mission, Bosch (1993:375-376) is against the complete abandonment of old paradigms for the new ones in theological discourses. He (1993:375-376) maintains that there is always a continuity and change between old and new paradigms. However, this is problematic when it comes to non-theological meanings in old concepts attached to the new paradigms as these can diminish or compromise fundamental theological aspects. In other words, older meanings associated with these older concepts that are attached to the new models can influence how people view these new models. Teresa (2015) captures this concern in her assertion that:

\footnotetext{
... the danger in trying to create new meanings with such existing forms is that the old meanings are still attached, and it could result in the people having syncretized understanding and practice rather than one rooted in Scriptures. (p. 18)
}

In substantiation, even though Bediako seems to have commenced with his ancestral incarnational Christology on the basis of Scripture, ${ }^{6}$ one is uncertain whether he consistently remains within the biblical framework (Wagenaar 1999:373). He seems to follow the Evangelical doctrine of Christ's incarnation, yet introduces Jesus Christ in African cultural trappings. A deviation from the biblical concept about Christ as one being with God the Father. By applying the ancestral category to Christ ${ }^{7}$ Bediako's hypothesis of contextualisation

6.Methodologically Olsen (1997:258) argues that Bediako's ancestral incarnational Christological concept is grounded in Scripture. This is because Bediako understands that in elaborating Christology, one has 'to be faithful to Jesus and the witness of the Gospels and the Apostles'. This seems to be evident in Bediako's (1994:99; 2000:24) critique of John Pobee (his contemporary leading Ghanaian theologian, who also challenges the traditional African ancestral worldview with Christ as the Great ancestor), who 'approached the problem largely through Akan wisdom sayings and proverbs', thus, 'he does not deal sufficiently with the religious nature of the question'. It is from this backdrop that Wendland (1995:113-114) agrees with Olsen in his classical evaluation of current contributions in African Christologies, since he highly rated Bediako's ancestral Christology as 'the best presentation of a context sensitive Christology', which is grounded in Scripture.

7.Bediako is 'approaching Christology through ancestral perspective', which is an ongoing endeavour for many African theologians (Wacheche 2012:27). Besides Bediako many African theologians like Bujo (1992:79), Kabasele (1991:123-124) Kwesi (1984:197-198), Milingo (1984:85), Nyamiti (2006:24), Pobee (1979:94) and Kwesi (1984:197-198), Milingo (1984:85), Nyamiti (2006:24), Pobee (1979:94) and
many more, are approaching the subject of Christology from an ancestral perspective. tends to replace one problem for another. He is merely exchanging a Christ in western trappings - for a Christ in African cultural trappings, since, in the authors opinions, Christ as ancestor is not representative of a predominantly biblical view. Hence in order to enable African Christians to break away from their predominant perception of Christ as foreign to them, we implore scholars to establish a biblicaltheological model which best describes Christ's identification with African Christians other than the ancestral category. This alternative biblical-theological model should underscore the complete identification of Christ with African Christians without diminishing the actuality of Christ as God incarnate or encouraging syncretism in African Christianity or reducing the validity of African contextual needs.

\section{Conclusion}

This article has critically analysed Bediako's ancestral incarnational Christological model as a response to the foreignness of Christ in African Christianity. It argues that in deforeignising Christ in African Christianity, Bediako contends that both the divinity and humanity of Christ are important. Nonetheless, he commences with the divinity of Christ in order to stress the Godhood of Christ, therefore establishing the universality of Christ. Even though Christ is a Jew by birth, Bediako understands that his divinity precedes his particularity as a Jew. In asserting this Bediako moved towards his conclusion that in the mystery of the incarnation, Christ assumed the universal human nature, giving him authority as the ancestor of every Christian, including African Christians. This is to say Christ's uncompounded divine-human nature qualifies him as an ancestor for all people. Bediako further embedded the universal ancestorship of Christ with a close link between the doctrine of creation and that of redemption, also attending to the centrality of faith in African Christians' appropriation of the divine promises given to the patriarchs of Israel throughout its ancient history.

However, Bediako's application of the ancestral category to Christ seems failing to reflect a biblical language about Christ. His application of the ancestral category to Christ appears to encourage African Christians to continuously think of Christ in their former traditional way of ancestor. Because of this African Christians can continue to hold on to both Christ and their natural ancestors for spiritual security. This blurs the actuality that Christ is beyond the category of ancestor due to Him also being the incarnate God. Owing to the above-mentioned challenges, if we desire to deforeignise Christ in African Christianity without diminishing the actuality of Christ as God incarnate or encouraging syncretism, we conclude that there is a need for scholars to search for an alternative biblical-theological model that best describes Christ's identification with Africans other than the ancestral model. This alternative biblical-theological framework should enable African Christians to claim complete solidarity with Christ everywhere without the incarnational Christological challenge emphasising the foreignness of Jesus Christ. 


\section{Acknowledgements Competing interests}

The authors declare that they have no financial or personal relationships which may have inappropriately influenced them in writing this article.

\section{Authors' contributions}

R.P. and C.M. conceptualised the article and its outline, including formulating the core research ideas and theme. C.M. mined the data and conducted preliminary data analysis. Both engaged in the writing, editing, critical reviewing and refining of the article for its completion.

\section{References}

Adewuya, A.J., 2012, 'The spiritual powers of Ephesians 6:10-18 in the light of African Pentecostal spirituality', Bulletin for Biblical Research 22(2), 251-258.

Afeke, B. \& Verster, P., 2004, 'Christianisation of ancestor veneration within African traditional religion: An evaluation', In die Skriflig 38(1), 47-61. http://dx.doi. traditional religion: An evalu

Aguwa, J.C., 2007, 'Mission, colonialism, and the supplanting of African religious and medical practices', in M.K. Asante (ed.), African studies: History, politics, economics, culture, pp. 127-145, Taylor \& Francis, Routledge.

Agyarko, O.R., 2010, 'God of life: Rethinking the Akan Christian concept of God in the light of the ecological crisis', Ecumenical Review 65(1), 51-66. http://dx.doi. org/10.1111/erev.12026

Aho Ekue, A.A., 2005, 'Troubled but not destroyed: The development of African theologies and the paradigm of theology of reconstruction', in K. Koschorke (ed.) African identities and world Christianity in the twentieth century, pp. 101-112, Harrassowitz, Wiesbaden.

Amanze, J.N., 2011, 'Contextuality: African spirituality as a catalyst for spiritual formation in theological education in Africa', Ogbomoso Journal of Theology 16(2), 1-23.

Anderson, A., 2001, 'Stretching the definitions? Pneumatology and syncretism in African Pentecostalism', Journal of Pentecostal Theology 10(1), 98-111. http:// dx.doi.org/10.1177/096673690101000106

Asamoah-Gyadu, K.J.A., 2009, 'Bediako, Kwame, 1945-2008: Bediako of Africa: A late 20th century outstanding theologian and a teacher', Mission Studies 26(1), 5-16. $\mathrm{http}: / / \mathrm{dx}$.doi.org/10.1163/157338309X442335

Banda, C., 2005, 'The sufficiency of Christ in Africa: A Christological challenge from African traditional religion', MA dissertation, Faculty of Theology, University of South Africa, Pretoria.

Bediako, K., 1994, 'Jesus in the African culture: A Ghanaian perspective', in A. Dryrness (ed.), Emerging voices in global Christian theology, pp. 93-121, Zondervan, Grand Rapids, MI.

Bediako, K., 1995, Christianity in Africa: The renewal of a non-western religion Edinburgh University Press, Edinburgh.

Bediako, K., 2000, Jesus in Africa: The Christian gospel in African history and experience, Regnum Africa, Yaounde.

Bediako, K., 2004, Jesus and the gospel in Africa: History and experience, Orbis Book, New York.

Bosch, D.J., 1993, Transforming mission: Paradigm shifts in theology of mission, Orbis Books, Maryknoll, MO.

Bujo, B., 1992, African theology in its social context, Orbis Books, Maryknoll, MO.

Chitando, E., 2005, 'Missionary attitudes towards African Traditional Religions and Hinduism: A comparative survey', in K. Koschorke (ed.), African identities and world Christianity in the twentieth century, pp. 181-197, Harrassowitz, Wiesbaden.

Cranfield, C.E.D., 1975, The international critical commentary: A critical and exegetical commentary on the epistle to the Romans, Clark, Edinburgh.

Dyrness, W.A., 1990, Learning about theology from the third world, Zondervan, Grand Rapids, MI.

Ejenobo, D.T., 2009, 'The mystical element in Paul's theology of the Holy Spirit: An African interpretation', Asia Journal of Theology 23(1), 69-81.

Ezigbo, V.I., 2008, 'Contextualizing the Christ-event: A Christological study of the interpretations and appropriations of Jesus Christ in Nigerian Christianity', PhD thesis, Faculty of Theology, University of Edinburgh, Edinburgh.

Haar, G.T., 2009, How God became African: African spirituality and western secular thought, University of Pennsylvania Press, Philadelphia, PA.

Hood, R.E., 1990, Must God remain Greek? Afro cultures and God-talk, Fortress, Minneapolis, MN.

Hultgren, A.J., 2011, Paul's letter to the Romans: A commentary, Eerdmans, Grand Rapids, MI.
Imasogie, O., 1983, Guidelines for Christian theology in Africa, Africa Christian Press, Achimota.

Ishola, A.S., 2002, 'Christianity vis-à-vis Traditional Religions', Southwestern Journal of Theology 44(2), 44-60.

Kabasele, F., 1991, 'Christ as ancestor and elder brother', in R. Schreiter (ed.), Faces of Jesus in Africa, pp. 123-124, Orbis Books, Maryknoll, MO.

Kalu, O.U., 2007, African Christianity: An African story, Africa World Press, Trenton, NJ.

Kok, D.B., 2005, Christianity and African Traditional Religion: Two realities of a different kind, Kachere Series, Zomba.

Kruse, C.G., 2012, Paul's letter to the Romans, Eerdmans, Grand Rapids, MI.

Kunhiyop, S.W., 2012, African Christian theology, Zondervan, Grand Rapids, MI.

Kwesi, D., 1984, Theology in Africa, Orbis Books, Maryknoll, MO.

Light, V.E., 2010, The Evangelical Church in Africa: Towards a model for Christian discipleship, South African Theological Seminary, Johannesburg.

Louw, D.J., 2002, 'A practical theological ecclesiological of relocalisation and globalisation from below: Towards a viable African Renaissance', Journal of Theology for Southern Africa 112, 69-87.

Lugira, A.M., 2009, World Religions: African traditional religion, 3rd edn., Chelsea House Publishers, New York.

Mashau, D.T., 2009, 'A reformed missional perspective on secularism and pluralism in Africa: Their impact on African Christianity and the revival of Traditional Religion', Calvin Theological Journal 44(1), 108-126.

Mbiti, J., 1989, African religions and philosophy, Heinemann, London.

Michael, M., 2013, Christian theology and African traditions, Lutterworth Press, Cambridge.

Milingo, E., 1984, The world in between: Christian healing and the struggle for spiritual survival, Orbis Books, Maryknoll, MO.

Mkole, J.C.L., 2000, 'Mark 14:62: Substantial compendium of New Testament Christology', HTS 56(4), 1119-1145.

Mugabe, H.J., 1991, 'Christology in an African context', Review \& Expositor 88(4), 343-355. http://dx.doi.org/10.1177/003463739108800403

Ncozana, S.S., 2002, The spirit dimension in African Christianity: A pastoral study among the Tumbuka people of northern Malawi, Christian Literature Association in Malawi, Blantyre.

Nkansah-Obrempong, J., 2010, 'Evangelical theology in Africa: Ways, perspectives, and dilemmas', Evangelical Review of Theology 34(4), 293-299.

Nurnberger, K., 2007, The living dead and the living God: Christ and the ancestors in changing Africa, CB Powell Bible Centre, Pretoria.

Nyamiti, C., 1989, 'African Christologies today', in J.N.K. Mugambi \& L. Magesa (eds.), Jesus in African Christianity: Experimentation and diversity in African Christology, pp. 17-39, Acton Publishers, Nairobi.

Nyamiti, C., 2006, Studies in African Christian theology, vol. 2: Jesus Christ, the ancestor of humankind: An essay on African Christianity, CUEA Publications, Nairobi.

Obituary, 2009, 'Professors Kwame Bediako and Ogbu Kalu', Journal of Theology for Southern Africa 133, 7.

Oladipo, C., 2010, 'African Christendom in the twenty-first century', Ogbomoso Journal of Theology 15(2), 33-71.

Oladosu, O.A., 2012, 'Ancestral veneration in the religious expression of the indigenous Aladura Churches', Ogbomoso Journal of Theology 17(2), 159-171.

Olsen, J.H., 1997, 'Contextualised Christology in tropical Africa', Svensk Missionstidskrift $85(3-4), 247-267$.

Omenyo, C., 2008, 'Bediako Kwame, 1945-2008', Exchange 37(4), 387-389. http:// dx.doi.org/10.1163/157254308X355372

Palmer, T., 2008, 'Jesus Christ: Our ancestor?', Africa Journal of Evangelical Theology 27(1), 65-76.

Pobee, J., 1979, Towards an African theology, Abingdon, Nashville, TN.

Reed, R. \& Mtukwa, G., 2010, 'Christ our ancestor: African Christology and the danger of contextualization', Wesleyan Theological Journal 45(1), 144-163.

Salala, C., 1998, 'The world of the spirits: Basukuma Traditional Religion and biblical Christianity', in S. Ngewa, M. Shaw \& T. Tienou (eds.), Issues in African theology, pp. 133-138, East African Education Publishers, Nairobi.

Schaff, P. \& Wace, H., 1991, The seven ecumenical councils: The Nicene and PostNicene Fathers, 2nd edn., Eerdmans, Grand Rapids, MI.

Setiloane, G.M., 1976, The image of God among the Sotho-Tswana, Balkema, Rotterdam.

Shaw, M., 1996, The kingdom of God in Africa: A short history of African Christianity, Baker Books, Grand Rapids, MI.

Taylor, J.V., 1963, The primal vision: Christian presence amid African religion, SCM, London.

Teresa, C., 2015, 'A look at contextualisation: Historical background, definition, function, scope and models', Asian Journal of Pentecostal Studies 18(1), 3-19. 
Triebel, J., 2002, 'Living together with the ancestors: Ancestor veneration in Africa as a challenge for missiology', Missiology: An International Review 30(2), 187-197.

Turaki, Y., 2006, Foundations of African traditional religion and world-view, Word Alive Publishers, Nairobi.

Wacheche, P., 2012, 'Modern trends in Christianity', MA dissertation, Nairobi University, Nairobi.

Wagenaar, H., 1999, 'Theology, identity and the pre-Christian past: A critical analysis of Dr. Bediako's theology from a Frisian perspective', International Review of Mission 88(351), 364-380. http://dx.doi.org/10.1111/j.1758-6631.1999.tb00165.x
Waliggo, J.M., 1998, 'The African clan as the true model of the African church', in N.K. Mugambi \& L. Magesa (eds.), The church in African Christianity: Innovative essays in ecclesiology, 2nd edn., pp. 111-127, Acton Publishers, Nairobi.

Walls, A., 2008, 'Bediako, Kwame, 1945-2008', International Bulletin of Mission Research 32(4), 188-193. http://dx.doi.org/10.1177/239693930803200405

Wendland, E.R., 1995, 'Recent contributions in African theology: A book review article', Africa Journal of Evangelical Theology 14(2), 113-123.

Wijsen, F., 2000, 'Popular Christianity in East Africa: Inculturation and syncretism', Exchange 29(1), 37-60. http://dx.doi.org/10.1163/157254300X00049 